\title{
What Does It Mean to Be a(n Italian) Borderland? Recent Literature on Italy's 'New Provinces' of South Tyrol and the Julian March
}

\author{
Eden McLean \\ Department of History, Auburn University, USA \\ ekmclean@auburn.edu
}

Marco Bellabarba and Gustavo Corni, eds., Il Trentino e i trentini nella Grande guerra: Nuove prospettive di ricerca (Bologna: Società editrice il Mulino, 2017), 201 pp. (pb), € 19.00, ISBN 9788815273499.

Marina Cattaruzza, Italy and Its Eastern Border, 1866-2016, Daniela Gobetti, trans. (New York: Routledge, 2017), 303 pp. (hb), \$136.00, ISBN 9781138329867.

Andrea Di Michele, Tra due divise: La Grande Guerra degli italiani d'Austria (Bari: Editori Laterza, 2018), 256 pp. (pb), € 24.00, ISBN 9788858127780.

Georg Grote and Hannes Obermair, eds, A Land on the Threshold: South Tyrolean Transformations, 1915-2015 (Bern: Peter Lang, 2017), 418 pp. (hb), \$106.00, ISBN 9783034322409.

Christian Jennings, Flashpoint Trieste: The First Battle of the Cold War (Lebanon, NH: University Press of New England, 2017), 302 pp. (hb), \$29.95, ISBN 9781512601725.

Roberta Pergher, Mussolini's Nation-Empire: Sovereignty and Settlement in Italy's Borderlands, 19221943 (Cambridge: Cambridge University Press, 2017), 296 pp. (hb), \$105.00, ISBN 9781108414784.

In the era of the Schengen Area (at least in the days before Covid-19), travel from Munich to Bozen/ Bolzano or Ljubljana to Trst/Trieste is a decidedly unremarkable, albeit beautiful, adventure. Just as meaningful as the lack of border controls, travellers find all public signage in both Italian and German (and sometimes Ladin, too) upon arrival in Bozen/Bolzano. Signs in the streets of Trst/ Trieste less reliably have Slovene alongside the Italian, but assistance with translation can be found with little difficulty. The Italian autonomous regions 'with special statutes' in which these cities reside Trentino-Alto Adige (South Tyrol) and Friuli Venezia Giulia (the Julian March) - are multilingual territories that, at least on an official level, embrace a multiethnic heritage and reality. In fact, Trentino-Alto Adige's consociational democracy is widely regarded among political scientists as an international role model for how states can successfully protect and give voice to minority populations. ${ }^{1}$ Those unfamiliar with the more recent history of these regions might be surprised to learn

\footnotetext{
1 In contrast to majoritarian democracy, consociational democracy, or power-sharing democracy, guarantees political representation for all major communal groups in societies deeply divided along ethnic, religious or ideological lines. For a discussion of this system, see Arend Lijphart, 'Constitutional Design for Divided Societies', Journal of Democracy, 15, 2 (2004). In the case of Trentino-Alto Adige, 'Germans', 'Italians' and 'Ladins' are all guaranteed political representation and power in provincial and regional governments, regardless of their relative proportion of the population at large. For analysis of the political system in Trentino-Alto Adige, see Stephen J. Larin and Marc Roggla, 'Participatory Consociationalism? No, but South Tyrol's Autonomy Convention is evidence that power-sharing can transform conflicts', Nations and Nationalism, 25, 3 (July 2019); Günther Pallaver, 'South Tyrol's Changing Political System: From Dissociative

(C) The Author(s), 2021. Published by Cambridge University Press. This is an Open Access article, distributed under the terms of the Creative Commons Attribution licence (http://creativecommons.org/licenses/by/4.0/), which permits unrestricted re-use, distribution, and reproduction in any medium, provided the original work is properly cited.
} 
of these avowedly multiethnic political and cultural structures. For much of the first half of the twentieth century, the regions' two states - Austria-Hungary until 1919 and thereafter Italy - employed the 'nationality principle' to define policies and populations in these territories. As in most of Europe at the time, sovereignty was increasingly predicated on the contemporary ideal of the nation state, in which borders, ethnicity, language and citizenship were all bound together. Of course, as a multiethnic empire, Austria-Hungary was much more concerned about centralising state authority (and then fighting a world war) than national homogeneity, while Italy's nationalisation campaign in the interwar period became fundamental to its presence in the new provinces. Still, both states sought to classify and ultimately to control their border populations by privileging ethnolinguistic categories of citizenship.

The story of the nationalisation of borderlands - or states' failure to do so - is a rather familiar one by now, with the robust expansion of borderland studies over the last twenty years. ${ }^{2}$ The four monographs and two edited volumes under review here illustrate the similarities these territories and populations share with other borderlands, and particularly those whose borders were disputed in the twentieth century. The authors of these works employ the concept and space of the borderland as a means to approach questions of political sovereignty and collective identification in relation to much larger international, supra-regional or transnational questions. This stands in contrast to the work of previous scholars (and sometimes the beliefs of the residents) of the Italian borderlands who have tended to categorise the twentieth-century histories of Trentino-Alto Adige and Friuli Venezia Giulia as distinct and 'separate' from the history of the Italian nation state. ${ }^{3}$ Each of the reviewed works attempts to grapple with the intertwined questions of what it means to be both an 'Italian' borderland and an 'Italian' in the borderlands. A secondary, though related, project for many of these authors is to place these jurisdictional 'peripheries' at the centre of national and international politics. By employing the methodologies of borderland studies, these scholars argue unequivocally that the modern history of Italy's border regions is inextricably connected to larger conversations about how Italy and modern Europe have conceptualised the nation state, minority populations and collective identifications.

All six volumes take as their starting point the now well-established idea that borders are not mere expressions of geopolitical power, nor are they clear demarcations of discrete and homogenous 'national' populations. Instead, the concept of the borderland helps capture the reality of spaces where often power is contested; definitions of ethnicity, language and identity are not simple; boundaries are permeable and communities do not conform to obvious categorisations based on nationality (or other identifiers). In contrast to the simplistic binaries such as our side / their side, us / them,

on the Road to Associative Conflict Resolution', Nationalities Papers, 42, 3 (2014). Jan Markusse, 'Power-Sharing and

“Consociational Democracy" in South Tyrol', GeoJournal, 43, 1 (1997).

2 In the European context, many recent studies on the nationalisation of borderlands has considered territories in the former Habsburg lands. For example Pamela Ballinger, 'Borders of the Nation, Borders of Citizenship: Italian Repatriation and the Redefintion of National Identity after World War II', Society for Comparative Study of Society and History, 49, 3 (2007); Tara Zahra, Kidnapped Souls: National Indifference and the Battle for Children in the Bohemian Lands, 1900-1948 (Ithaca, NY: Cornell University Press, 2008); Rogers Brubaker, 'Accidental Diasporas and External 'Homelands' in Central and Eastern Europe: Past and Present', Political Science Series, 71 (2000); Jeremy King, 'The Nationalization of East Central Europe: Ethnicism, Ethnicity, and Beyond', in Maria Bucur and Nancy M. Wingfield, eds., Staging the Past: The Politics of Commemoration in Habsburg Central Europe, 1848 to the Present (West Lafayette, IN: Purdue University Press, 2001); Jeremy King, Budweisers into Czechs and Germans: A Local History of Bohemian Politics, 1848-1948 (Princeton, NJ: Princeton University Press, 2002); Pieter M. Judson, Guardians of the Nation: Activists on the Language Frontiers of Imperial Austria (Cambridge, MA: Harvard University Press, 2006); Nancy M. Wingfield, Flag Wars and Stone Saints: How the Bohemian Lands Became Czech (Cambridge, MA: Harvard University Press, 2007); Maura Hametz, In the Name of Italy: Nation, Family, and Patriotism in a Fascist Court (New York: Fordham University Press, 2012); Dominique Kirchner Reill, Nationalists Who Feared the Nation: Adriatic Multi-Nationalism in Habsburg Dalmatia, Trieste, and Venice (Stanford: Stanford University Press, 2012).

3 See, for example, Georg Grote, as cited in Eva Pfanzelter, 'The (Un)digested Memory of the South Tyrolean Resettlement in 1939', in Georg Grote and Hannes Obermair, eds., A Land on the Threshold: South Tyrolean Transformations, 1915-2015, (Bern: Peter Lang, 2017), 123. 
national / alien, borderlands often display more complex compositions of cultures and identifications. ${ }^{4}$ Even the more recent scholarly trend to describe cultures, populations and regions as 'hybrid' imposes the limits of well-defined and familiar 'identities' and curtails the possibility of a spectrum of identifications. ${ }^{5}$ The literature considered here helps articulate some of the many layers of identifications in South Tyrol and the northeastern Adriatic coast, as well as their interactions with broader historical narratives.

Some of the most valuable contributions of the six works result from their ability to place the twentieth-century history of these 'Italian frontiers' within local, national and international contexts. Andrea Di Michele, in reference to the Italian-speaking soldiers in the Austro-Hungarian military during the First World War, points out that these soldiers' experiences were located 'halfway between regional history and global history', something that could be said more generally of all the research discussed here. ${ }^{6}$ Moreover, the editors of $A$ Land on the Threshold argue that South Tyrol today uses its position 'on the threshold' as a defining feature, and to advance the region's claims of international significance. ${ }^{7}$ Still, at the same time that many of these authors recognise the fluidity of collective identifications and the virtual impossibility of forcing groups to conform to state-defined 'ethnic boxes', these volumes demonstrate some of the challenges inherent in moving beyond conventional categories of territory, time and collectivity. ${ }^{8}$

While the six studies push against the conceptual framework of borders as barriers, they generally accept the (contradictory) framework produced by the Italian state post-annexation, one that simultaneously positions these regions as part of and distinct from the Italian nation state. And it is true that, despite the two regions' historical similarities, their more recent differences are extensive and make direct comparisons somewhat difficult. Italian speakers in Venezia Giulia had long shared political and cultural interests with those in southern Tyrol, but the addition of the Veneto to the Italian Kingdom in 1866 produced a territorial wedge between the two Habsburg border regions and their Italian-speaking populations. This separation was not merely geographical, but also in the residents' ethnic, economic and historical relationships to their landscapes, the Habsburg state in Vienna and members of other ethnolinguistic communities. One manifestation of this estrangement was an expansion of Italian irredentist and nationalist associations in Trieste and its surroundings in the decades before the outbreak of the First World War that was never seen in Trent. ${ }^{9}$ It is not surprising, then, that four of the six books focus on a single border region, sometimes comparing the experiences of one with the other, but not at any length.

Andrea Di Michele's Between Two Uniforms: The Great War for Austria's Italians (Tra due divisi: La Grande Guerra degli italiani d'Austria) and Roberta Pergher's, Mussolini's Nation-Empire: Sovereignty and Settlement in Italy's Borderlands, 1922-1943 are exceptions in that each employ

4 Here I follow the assessment of Fredrick Cooper and Rogers Brubaker that the term 'identity' is overly vague and therefore of limited use. Rogers Brubaker and Frederick Cooper, 'Beyond "Identity", Theory and Society, 29, 1 (2000).

5 As Tara Zahra succinctly explains, 'both the concept of the hybrid and that of the borderland smell of nationalism'. Zahra, Kidnapped Souls, 8 .

6 Andrea Di Michele, Tra due divise: La Grande Guerra degli italiani d'Austria (Bari: Editori Laterza, 2018 ), 223.

7 Georg Grote and Hannes Obermair, 'Introduction: South Tyrol: Land on a Threshold. Really?' in Grote and Obermair, A Land on the Threshold, xix. The phrase itself does not seem to convey Grote and Obermair's theme of a region 'in between' - instead suggesting that the region and population are on the verge of something (though what is not quite clear) - but all the included authors are interested in South Tyrol's multifaceted liminality and connectivity.

8 Rok Stergar and Tamara Scheer, 'Ethnic Boxes: The Unintended Consequences of Habsburg Bureaucratic Classification', Nationalities Papers, 46, 4 (2018).

9 In part this divergence resulted from the socioeconomic composition of each territory - the Italian-speaking population of the Julian March was much more urban and wealthy than those in South Tyrol - but, according to Marina Cattaruzza in Italy and Its Eastern Border, the increasingly anti-Slavic sentiment among Italian-speaking intellectuals and professionals in the Julian March was of greater importance. Marina Cattaruzza, Italy and Its Eastern Border, 1866-2016, trans. Daniela Gobetti (New York: Routledge, 2017), 32. In fact, Cattaruzza argues convincingly, 'the struggle against Slavism became the defining characteristic of the Italian national movement along the Austrian littoral more or less in the 1880s, and, therefore, the distinctive feature of nationalism during its transition to a mass movement'. Ibid., 36. 
multiple borderlands to ground their analysis in larger conversations about central-state policies toward minority populations. Di Michele is especially adept at examining the linkages between the populations of the two former Habsburg territories. He traces the experiences of (and responses to) Italian-speaking members of the Austro-Hungarian military, follows some of them to Russian POW camps and then tracks their round-the-world journey to return to their homes and their new Italian nationality, which for some was not until 1922. By studying Italian speakers fighting for the Habsburg Monarchy away from their homes and families, Di Michele is able to explore the divergent treatments these soldiers received from the governments in both Vienna and Rome. ${ }^{10}$ Pergher's research, by contrast, takes the innovative approach of comparing the fascist state's presence in South Tyrol to that in Libya - Italy's so-called 'fourth shore' - to explore concepts of state sovereignty during the ventennio. This choice emphasises the very ambiguous distinction between an Italian colony and a 'new province' under fascist control, bringing Pergher to the insightful description of fascist Italy as a 'nation-empire'. The comparative approach of both these works - like reading the books under review in conversation with each other - raises important questions about the relationship of the regions to the central state in Rome (and Vienna) and suggests exciting avenues for further research.

With some valuable exceptions, the majority of the scholars focus on the tensions and negotiations between self- and state-identifications, political rhetoric and lived reality in the first half of the twentieth century. More generally, they explore the concept of Italian-ness (italianità) and its counterparts in the period between Italian unification (1860) and the establishment of the Republic of Italy (1946), when it was not entirely certain that these territories would become or remain constituent parts of the Italian nation state. Both Cattaruzza and Di Michele spend their early chapters providing nineteenthcentury context for the conflicts of the interwar period. The nationalist conceptions of sovereignty that were elaborated and expanded in the nineteenth century played a critical role in the development of Italy's borderlands in the latter. As both authors contend, the establishment of elite nationalist circles throughout the Habsburg Empire (as well as much of the rest of Europe) meant that by the early twentieth century the nationality principle became 'the basic criterion of the legitimation for establishing borders'. ${ }^{11}$ Cattaruzza explains further that the social, economic and political transformations of the nineteenth and early twentieth centuries 'made it imperative for all European states to promote the saturation of border areas as completely as possible. This ambition meant ensuring a degree of control at the periphery comparable to that ensured at the core, promoting the nationalisation of the entire population and exercising unquestioned sovereignty on the entire territory.' ${ }^{12}$ The idea that state borders ought to conform to ethnolinguistic boundaries - the theoretical framework for the policy of national self-determination - became the basis upon which nation states such as Italy laid claim to territory outside their borders.

Of course, the nationality principle and its rigid prioritisation of ethnolinguistic identity was inherently problematic for multilingual empire states like Austria-Hungary. Scholarship on the role of nationalist movements in the collapse of the Habsburg Empire has seen significant growth; Cattaruzza's expansive study of Italy's eastern borderlands over the last 150 years - originally published in 2007 in Italian as L'Italia e il confine orientale - joins this literature in analysing the political rhetoric and behind the scenes manoeuvring that elite nationalists and the Italian government employed to try to secure national sovereignty over territory along the Adriatic coast. ${ }^{13}$ On the one hand, she argues that the status of Italian-speaking populations along the Adriatic coast played a

10 Another recent example of this approach that analyses Italy's educational policies in the 'new provinces' in the five years after the war is Andrea Dessardo, Le ultime trincee: Politica e vita scolastica a Trento e Trieste, 1918-1923 (Brescia: Editrice La Scuola, 2016).

11 Cattaruzza, Italy and Its Eastern Border, 2. While this term is more often used in matters of international law, its application to connote the theoretical foundation of modern Western conception of nation building is apt.

12 Ibid., 281.

13 Some excellent examples of this scholarship are Judson, Guardians of the Nation and Gary B. Cohen, 'Nationalist Politics and the Dynamics of State and Civil Society in the Habsburg Monarchy, 1867-1914', Central European History, 40 (2007). 
central role in modern Italy's 'power policy', especially in the first half of the twentieth century. ${ }^{14}$ On the other hand, she uses the Adriatic littoral as a new vantage point from which to observe 'the waxing and waning of Italian patriotism' from the perspective of Italy's 'political elites' over the course of Italy's modern history. ${ }^{15}$ As one of the foremost scholars on Italy's 'eastern border', Cattaruzza's work presents somewhat as a summative analysis of the northern and eastern Adriatic in Italian foreign policy (though she also wrote another volume, Italy and the Adriatic Question (L'Italia e la questione adriatica), in 2014 between the work's original publication and its English translation). Sweeping in its scope, one of its many thoughtful contributions is its use of the long view of history to reveal important connections across wars and regimes in the region's relationship to Italy and ideas of national belonging.

Only recently have scholars started connecting the Trentines of South Tyrol to the larger discussion about nationalist agitation in the Habsburg Empire, and both Di Michele's Between Two Uniforms and Marco Bellabarba and Gustavo Corni's collection of essays The Trentino and the Trentines in the Great War (Il Trentino e i trentini nella Grande Guerra) are excellent examples of the sophisticated new scholarship historians are producing about the region on the eve of Italian annexation. Importantly, these works remind us that thinking about turn of the century nationalism in multilingual empires such as Austria-Hungary (or anywhere, really) requires us to move away from the assumption that the mere fact of speaking Italian conferred individual and collective identification with the Italian nation state. Despite the rise of nationalist organisations in Trieste, Di Michele argues that in the decades before the First World War Italian speakers in South Tyrol - even those actively working to defend and promote italianità within their communities - did not argue for a separation from the Dual Monarchy. Instead, the majority of them advocated for more autonomy within the imperial administration. ${ }^{16}$ Rather than viewing themselves as 'Italians', Simone Attlio Bellezza argues in his contribution to Bellabarba and Corni's collection, these Italian speakers viewed themselves as having a 'specific Trentine identity' with allegiance to their little fatherland (piccola patria) in the Dolomites (as well as the Catholic Church) before any concept of an Italian nation. ${ }^{17}$

Unsurprisingly, the recent centenary of the First World War and then Italy's annexation of Trentino-Alto Adige and Venezia Giulia (as well as Istria and portions of Dalmatia) in 1919 inspired a proliferation of valuable works on the war and interwar years. Though perhaps not breaking new ground in terms of connections across temporal periods, the developing research in the volumes from Di Michele and Bellabarba and Corni contribute to a much-needed revision of the so-called 'Italian war' of 1914-8. Italian historians have until recently portrayed Italians' experience of the First World War as one simply and purely as either patriots or victims. Meanwhile, the broader scholarly conversation about the first global war has largely ignored or even dismissed Italy's and Italians' experiences. Marco Mondini's review of existing First World War scholarship is therefore understandably critical of the inadequate coverage of 'Italy's war', but it also rightly emphasises the promising interventions in new research - such as that contained in Bellabarba and Corni's collection of essays and Di Michele's monograph - which help to remedy these tendencies. For Mondini, recognising the Italian-speaking populations of the former Habsburg Empire - those who would become Italian

Reill, Nationalists Who Feared the Nation; Stergar and Scheer, 'Ethnic Boxes: The Unintended Consequences of Habsburg Bureaucratic Classification'.

14 Cattaruzza, Italy and Its Eastern Border, 7.

15 Ibid., 4.

16 Di Michele, Tra due divisi, 36.

17 Simone Attilio Bellezza, 'Identità prigioniere. I trentini in Russia, 1914-1921' in Marco Bellabarba and Gustavo Corni, eds., Il Trentino e i trentini nella Grande guerra: Nuove prospettive di ricerca, (Bologna: Società editrice il Mulino, 2017), 126, 132. Despite her argument about Italian-speaking Julians' decided turn toward irredentism after Italian unification, Cattaruzza explains that 'Italian language and culture spread its influence far beyond the boundaries of Italian national identification, by providing essential features to a regional Dalmatian identity, in competition with Croatian or Serbian nationalization'. Cattaruzza, Italy and Its Eastern Border, 7. This sense of a particular Dalamatian italianità is central to Reill's argument in Reill, Nationalists Who Feared the Nation. 
citizens after the war - as part of Italy's war invites all 'Italians' to be part of the national experience. ${ }^{18}$ It also admits a more complex experience of war for Italian speakers. Finally, Mondini points out, it establishes an 'ideal premise for a more "European" and less narrowly "national" history' of the war experience, for which Italian scholars have been especially well known. ${ }^{19}$

This new turn in scholarship on the Italian war necessarily emphasises the complexities a multiethnic border region brought to a global war that was largely underpinned by nationalist ideologies. As a result, many of these new histories focus on examining issues of national identification and national allegiance among the soldier and civilian populations. In what to date is the most thorough analysis of the Italian-speaking soldiers in the Austro-Hungarian military during the war, Di Michele points out that a significant number of these studies rely on the personal letters and diaries of individual soldiers to explore the relative importance of national affiliation in their experiences of the war. Simone Attilio Bellezza's insightful piece on Italian-speaking POWs in Bellabarba and Corni's volume provides an excellent example of this methodology. By contrast, Di Michele and Alessandro Salvador identify 'Italian' soldiers as the Austro-Hungarian and Italian governments defined them. Employing categories of nationality as military and civilian officials conceived them (largely based on language) provides these authors with a wider lens to analyse the administrative and diplomatic decisions concerning these groups. Additionally, it allows them to consider the influence the state had on shaping the experiences and sentiments of its Italian-speaking population in a time of war. ${ }^{20}$

The story of Italian-speaking Austro-Hungarian POWs presents a clear example of the clash between state-sponsored concepts, and personal experiences of national belonging and is a primary concern of Di Michele's book and two chapters in Bellabarba and Corni's collection. Before Italy had even joined the war effort, Russian diplomats had contacted Rome with an offer to release the 'Italian' soldiers to Italian officials (at Italy's expense, of course). Salvador outlines - and Di Michele further elaborates on - the awkward diplomatic position this proposition presented the Italian government. Italy wanted to avoid further diplomatic tension with Russia and AustriaHungary, but it also had to negotiate its own understandings of italianità and national belonging. ${ }^{21}$ Did anyone who spoke Italian belong to the Italian nation? Did anyone who lived within the 'irredentist' regions belong to the Italian nation? Or did one need to have a certain Italian 'spirit', a loyalty to the concept of 'Italy', to belong to the nation state? This was a difficult set of considerations to navigate, particularly when combined with the political necessities of proving Italy's rightful claim on the Habsburg lands (to Italians as well as to international observers) used to justify Italy's entry into the war. ${ }^{22}$ Di Michele, Savador and Bellezza all depict how difficult it was for administrators to answer these questions; just as illuminating, these scholars describe how POWs understood the political importance of their own responses to these questions by soliciting advice about national allegiance from their families, setting up 'Italianisation' lessons in the camps and carefully avoiding any behavior that might suggest preference for one state or the other.

Bellabarba and Corni's volume also answers a more universal call to consider the wartime experiences of civilian populations in any understanding of modern war. The Trentino and Friuli Venezia Giulia are complicated territories and populations to examine in this regard because, like Alsace-Loraine, they were active war zones that required residents to respond as both combatants and civilians. As Francesco Frizzera highlights in his chapter on the forced evacuations of civilian populations on both sides of the Italian front, the reality of the First World War not only required the mobilisation of the entire population, but also the transformation of state institutions to

18 Marco Mondini, 'Lo sguardo bloccato. Il difficile rinnovamento della storiografia italiana sulla Grande guerra', in Bellabarba and Corni, Il Trentino e i trentini nella Grande guerra, 200.

19 Ibid. Also Anna Grillini, 'Il ritorno: donne e soldati alla prova della memoria. Il caso della Trentino e Suditrolo tra il 1919 e il 1924' in Ibid., 69.

20 Di Michele, Tra due divisi, $\mathrm{x}$.

21 Salvador, 'Patrioti o traditori?', in Bellabarba and Corni, Il Trentino e i trentini nella Grande guerra, 160.

22 Italian nationalists also wanted to encourage the growth of a relatively limited irredentist movement in those lands. Di Michele, Tra due divisi, 224-5. 
accommodate wartime needs. At least in the Trentino (though one assumes a similar project occurred in Friuli Venezia Giulia), Frizzera writes, that meant creating systems to evacuate or expel civilian populations who posed a potential threat - either to their official state of the Habsburg Empire or their future home of the Italian Kingdom. Italian scholars and nationalists have often highlighted the decision irredentists made to flee to Italy after the 1914 outbreak of war, but few have discussed or even acknowledged the approximately 235,000 Italian-speaking citizen subjects of the Dual Monarchy forcibly transferred to the interior of the empire, 'for the simple fact that they lived out the war outside the borders of the kingdom and did not possess Italian citizenship'. ${ }^{3}$ And yet these experiences undoubtedly had a lasting influence on how Italian speakers viewed the governments in Vienna and Rome long into the post-war years.

Italy was finally able to realise its irredentist ambitions in the aftermath of the First World War with the 'movement of borders over people' as opposed to the 'movement of people over borders', but it meant the territories' new administrators then faced the question of what to do with their new, non-Italian-speaking 'Italians,. ${ }^{24}$ More concerning, though, was the fact that even Italian speakers did not seem to embody italianità as Italian officials envisioned it. This realisation caused no small amount of consternation among bureaucrats who now had to navigate what exactly it meant to be 'Italian' and what place these new regions had within the Italian nation state. In other words, the conclusion of the Treaty of St. Germain in 1919 gave Italy external validation of its control over South Tyrol and Venezia Giulia, but, as Roberta Pergher notes in the opening of Mussolini's Nation-Empire, 'what was missing . . . across the national and colonial borderlands was a claim to sovereignty emanating from the 'communal body of the nation' ${ }^{25}$ Despite the diplomatic confirmation of Italian sovereignty and the supposed solidity of the new borders on the ground, these new borderlands were actually proving to be 'areas in which political sovereignty was 'indeterminate. ${ }^{26}$ Cattaruzza, too, explains that after the war 'the impression taking hold among the Italian occupying forces was that they did not find themselves in liberated lands . . . but in treacherous territory where dangers lay hidden and which could become the target of sudden attacks by foreign powers (chiefly Yugoslavia) ${ }^{27}$

This uncertainty was unquestionably a concern for Italy's post-war liberal regime, and Cattaruzza's use of the concept of frontier fascism illustrates the ever-greater importance and potential threat the border represented for an emerging post-war fascist movement. The alarm local Black Shirts (squadristi) felt about the (in)security of Italy's borderlands, fueled by a nationalism fundamentally based on anti-Slavic and anti-German sentiments, provided 'a political and ideological bond' that gave the early fascist movement in Italy's frontiers a unity of purpose lacking in much of the rest of the kingdom. ${ }^{28}$ In fact, Cattaruzza concludes not without reason, 'we may not be veering too far from the truth if we say that Fiume and Bolzano were training camps for fascism's rise to power. ${ }^{29}$ This interpretation of the early fascist activities in Italy's new provinces also provides a valuable framework for Pergher's book that explores how, once Benito Mussolini came to power, the fascist regime attempted to make Italian sovereignty in its European and African borderlands indisputable. ${ }^{30}$ Focusing her attention on South Tyrol and Libya, Pergher argues that in both locales, a radical nationalist regime wrestled with the challenges of consolidating rule over lands and people that were not selfevidently Italian. In both areas it experimented with how best to assert Italian sovereignty and how to

\footnotetext{
23 Francesco Frizzera, 'Spostamenti forzati, controllo poliziesco e politiche di assistenza. I profughi trentini nel contesto europeo', in Bellabarba and Corni, Il Trentino e i trentini nella Grande guerra, 18.

24 On the idea of the 'movement of borders over people' as a form of transnationalism, see Rogers Brubaker, Grounds for Difference (Cambridge, MA: Harvard University Press, 2015), 8 among other places.

25 Roberta Pergher, Mussolini's Nation-Empire: Sovereignty and Settlement in Italy's Borderlands, 1922-1943 (Cambridge: Cambridge University Press, 2018), 35.

26 Ibid., 15.

27 Cattaruzza, Italy and Its Eastern Border, 285.

28 Ibid., 125.

29 Ibid.

30 Pergher, Mussolini's Nation-Empire, 5.
} 
determine the boundaries of what and who was Italian'. ${ }^{31}$ Likewise in Friuli-Venezia Giulia 'Fascism tried to practice a policy of centralization, nationalization, and incorporation of the population into its mass organizations ${ }^{32}$ Italianisation, alongside fascistisation, was considered critical to political sovereignty under Mussolini's regime.

Numerous scholars have explored the ways in which the fascists tackled this project, most prominently through an official policy of linguistic 'denationalisation'. The institution of Italian as the only official language, alongside making the teaching of any other local language illegal outside of the Church, was indeed a powerful tool with which the fascist regime attempted to 'make Italians' and therefore Italian sovereignty. ${ }^{33}$ Cattaruzza again gives us useful terminology to understand these denationalisation efforts as a form of power consolidation: the concept of 'ethnic simplification' in its most straightforward sense refers to the process of ethnic cleansing through pressured population transfers that took place after the Second World War in Italy's former possessions along the Adriatic, but it can easily be deployed more broadly to describe fascist policies of Italianisation before the Second World War. In fact, each of the books considered here clarify how the ideological foundations of such a process were part and parcel of the nationality principle that brought these territories to the Italian side of the border after the First World War.

What makes Pergher's study pioneering - besides its comparative component - is her focus on state-sponsored settlement programmes as a way to achieve 'ethnic simplification' and establish Italian sovereignty in the borderlands. Pergher chronicles how the regime instituted a series of programmes and initiatives to transfer Italian citizens from the 'old provinces' to the new borderlands as ambassadors of italianità and, therefore, Italian power. ${ }^{34}$ Interestingly, and a potential subject for further research, these programmes not only brought 'Italians' to the borderlands but also sent borderlanders to the 'old provinces' to neutralise their potential threat to Italian sovereignty. As Pergher explains, the most dramatic and famous of these population transfers was the goal of a 1939 agreement between Adolf Hitler and Mussolini. The so-called 'option' this deal provided South Tyrolean German speakers was to renounce either their Italian citizenship and migrate to the Third Reich or their 'German-ness' and embrace the Italian-fascist state. This plan, which largely remained incomplete after the Second World War broke out, is overwhelmingly claimed as one of the region's most traumatic collective memories by residents and scholars alike. And as Eva Pfanzelter comments in her essay on the memory of the Option, it has only been recently - and especially within the field of public history - that interpretations of it have moved beyond claiming universal victimhood and have become more nuanced to face what Günther Pallaver and Leopold Steurer has characterised as 'a beginning civil war'. ${ }^{35}$

Often Italy's northern and eastern border regions are left out of more general histories of the Second World War. From the Italian perspective, the German Reich annexed South Tyrol and Friuli-Venezia Giulia after 8 September 1943, therefore excluding them from the Italian experience of the second half of the war (just as they long had been from the Italian narrative of the First World War). From the German perspective, Italy's border regions were relatively marginal pieces of its empire and therefore hardly in need of much attention. However, writers such as Christian Jennings illustrate how many of the tensions that underlay the Second World War, the post-war world and the Cold War were not only visible, but on centre stage in these regions. Moreover, Jennings, as well as Georg Grote in his chapter on the myth of the 'zero-hour principle', helps blur

\footnotetext{
31 Ibid., 14.

32 Cattaruzza, Italy and Its Eastern Border, 287.

33 Antonio Elorza, 'Alsace, South Tyrol, Basque Country (Euskadi): Denationalization and Identity', in Grote and Obermair, A Land on the Threshold, 321.

34 Pergher, Mussolini's Nation-Empire, 244.

35 Pfanzelter, 'The (Un)digested Memory of the South Tyrolean Resettlement in 1939', in Grote and Obermair, A Land on the Threshold, 138.
} 
the temporal boundaries between the Second World War and the Cold War, further underscoring the complexity of and interconnections between wartime alliances and the post-war order. ${ }^{36}$

Jennings' account of the military and diplomatic battle for Trieste at the close of the Second World War features the importance of the port city and its surrounding region in the emerging Cold War, though the author is more interested in telling a good story than making nuanced historical arguments. As Jennings explains, the American, British, Yugoslav and Soviet governments all believed gaining control over Trieste would be the key to controlling central Europe, thus making 'the strategic and tactical situation one of the most militarily and politically complex of the war' ${ }^{37}$ Jennings is not the first to write about Italy's position as a frontline in the emerging Cold War or about the so-called Trieste Question. ${ }^{38}$ Still, the journalist-cum-historian is able to show definitively how important the borderland city was in the development of international diplomacy in the mid-twentieth century.

In large part Jennings' success comes out of his ability to distil complex diplomatic and tactical concerns into an engaging story that anyone can appreciate. He untangles the violence and confusion and fear of those few harrowing months of 1945 and 1946 by leading his readers through the experiences of twelve participants in the battle for Trieste. New Zealand soldiers, Italian partisans, SS and fascist officers and British intelligence officers each play a role in simultaneously humanising and globalising the final days of the Second World War in a city that now few people (Americans, at least) could identify on a map. As an author appealing to a non-academic audience, Jennings is not as concerned with meticulous citations of his sources. While understandable, this has significant drawbacks for those readers who are curious about how he came to his interpretation of (generalisations about) certain parts of Italian history. ${ }^{39}$ More detailed citations and analysis would bring to the book's broader context the level of clarity and nuance that characterises his chronicle of the race for Trieste.

Only two of the six books - A Land on the Threshold and Italy and Its Eastern Border - explore at any length the history of these regions after the 1946 declaration of the Italian republic, but Cattaruzza and several contributors to Grote and Obermair's expansive collection of twenty-one essays on 'the dynamic effects of [South Tyrol's] geographical, political and cultural history since 1915' grapple with critical issues of the second half of the twentieth century. Perhaps one of the most provocative pieces from Grote and Obermair's volume was Grote's own contribution about the fallacy of the 'zerohour principle' that became so valuable to populations across Europe in the aftermath of the Second World War. The popular concept that 8 May 1945 essentially constituted an opportunity for Europeans to start afresh was especially significant, Grote explains, among German speakers in South Tyrol, many of whom had eagerly supported one or the other of the Nazi-fascist regimes, and plenty of others who had suffered at the hands of both. ${ }^{40}$ Grote's research complicates this

36 Beyond the ideological continuities the decided lack of de-fascistisaiton allowed among mid- and lower-level bureaucrats, Jennings demonstrates how the clear memories Austrians, Italians, Croats, Slovenes and Serbs had of who collaborated and who resisted during the war helped shape the violence in Friuli-Venezia Giulia, Istria and Dalmatia in the immediate post-war period. They also inspired many of the political parties and alliances in the new governments of Italy and Yugoslavia; it is no coincidence that 'Tito' and many voices involved in drafting Italy's new constitution were prominent anti-fascist partisans.

37 Christian Jennings, Flashpoint Trieste: The First Battle of the Cold War (Lebanon, NH: University Press of New England, 2017), 48.

38 Many scholars wrote about the Trieste Question from the late 1940s on, but for a sample of more recent scholarship, see Marina Cattaruzza, '1945: Alle origini della «questione di Trieste»', ventseco Ventunesimo Secolo, 4, 7 (2005); Roberto Giorgio Rabel, Between East and West: Trieste, the United States, and the Cold War, 1941-1954 (Durham, NC: Duke Univerity Press, 1988); Glenda Sluga, The Problem of Trieste and the Italo-Yugoslav Border: Difference, Identity, and Sovereignty in Twentieth-century Europe (Albany: State University of New York Press, 2001); Elena Aga Rossi and Victor Zaslavsky, Stalin and Togliatti: Italy and the Origins of the Cold War (Palo Alto, CA: Stanford University Press, 2011).

39 Particularly perplexing was his significant but uncited claim that by July 1943 Italy's 'Catholics risked vicious reprisals if the Pope protested too loudly about what was happening to Europe's Jews'. Jennings, Flashpoint Trieste, 85.

40 Georg Grote, 'Challenging the Zero-Hour Concept: Letters across Borders', in Grote and Obermair, A Land on the Threshold, 103. 
problematic boundary between old and new, past and future - the same temporal break Jennings explores from a different angle. To do so, Grote analyses a single collection of love letters written between 1945 and 1948 by two German speakers, one South Tyrolean in Austria and the other in southern Germany. What was particularly provocative in this essay was the idea that multiple layers of identification (re)emerged among German speakers as soon as the Third Reich was eliminated and the borders between Germany, Austria and South Tyrol were re-established. The concept of the 'Zero Hour' allowed for each of the German-speaking groups to assert a specific type of victimhood that necessitated their distancing from the others and, consequently, from moral responsibility for the events of the previous decade. As a result, the supposedly homogenous national group became divided in new and (perhaps) surprising ways in the immediate aftermath of Germany's greatest push to unite all German speakers.

Cattaruzza's account of the continued importance of the Trieste Question to Italian geopolitical interests, at least until 1954, further supports the obvious disconnect between communities' desires for a Zero Hour and the everyday reality of post-war life in the Italian borderlands. But perhaps just as critical to the debunking of the Zero Hour myth are the contributions from social psychologists, linguists, anthropologists and journalists contained in the later sections of Grote and Obermair's edited volume. These writers push back against the comfortable and comforting image of today's South Tyrol as a prime example of the successful empowerment of linguistic minorities within local governance and underscore the on-going questions about and tensions around collective identification and national belonging in South Tyrol. Though I don't believe any would argue the 1972 autonomy statute was not a necessary step in healing a deeply wounded region, Barbara Angerer and Chiara De Paoli do maintain that its work to protect the region's multilingual character actually confirmed the state-imposed categories of nationality that had caused so much pain in the first half of the twentieth century.

Other authors suggest alternative ways South Tyroleans can define their community that take into consideration the concentric contexts of the Dolomite region, Italian nation, European continent and global community. These contributors echo the questions Rome faced during the Great War: who is allowed to identify as Tyrolean / Italian / European? They challenge the academically-debunked but popularly-maintained idea of a 'historical' or 'traditional' or 'unchanging' character in the borderlands. The musicologist Bettina Friederike Haupt and architect Bettina Schlorhaufer demonstrate the rich and varied (rather than hybrid) nature of South Tyrolean culture that is, like culture everywhere, constantly undergoing revision. Similarly, Sarah Oberbichler, Julia Tapfer, Hans Karl Peterlini, Lucio Giudiceandrea and Aldo Mazza call for a South Tyrolean identity that recognises the constant revision of the population itself: the continued arrival of new 'others' in the region over the last thirty years first from the Balkans, then from South Asia and Africa - forces residents to explore who is allowed to be Tyrolean in either more restrictive or more expansive terms. Echoing Lucio Giudiceandrea and Aldo Mazza's call to focus on a communal project to live mit einander (with each other) rather than neben einander (next to each other) or ohne einander (without each other), Peterlini calls to look to the community's linguistic 'in-between' as a pedagogical space in which members can learn from and with each other.

These four monographs and two essay collections demonstrate the vibrancy of research on the Italian borderlands. More importantly, they illustrate the ways in which Italy's northern and eastern borderlands are both case studies in several fundamental concerns of Europe's twentieth century and stages upon which some of the most important battles of Europe's twentieth century have played out. So it is decidedly unfair of me to highlight the failure to answer a question the authors did not set out to resolve; at the same time, it is somewhat remarkable that little of the analysis in these six books - and in the recent literature on Italian borderlands more generally - tackles the complicated and occasionally quite violent process of creating autonomous regions of these lands in the post-Second World War period. The literature that does exist continues to frame itself around the only somewhat helpful historical turning point of 1945 that scholars (including myself) have largely internalised. Cattaruzza works to erase this demarcation in her narrative of Italy's eastern frontier and maintains 
1954 as the key point at which the eastern border with Yugoslavia ceased to be a major consideration in Italian foreign policy. And while several of the authors in Grote and Obermair's collection work to expose some of the new(er) fault lines within South Tyrolean society, no one analyses the years between 1945 and 1972 that played a fundamental role in establishing those new margins.

It is interesting, too, that religion played little role in these studies that take seriously the question of borderland identity. The Catholic and Eastern Orthodox Churches are foundational organisations in these regions, and while their influence has waned over the last generation or two, they feature prominently as essential components to the self-identification of many borderlanders, regardless of their linguistic heritage or preference. Exploring the ways in which religious faith created some and bridged other differences within these regions might provide a fruitful avenue for acknowledging categories of identification that ignore or develop around border walls. More generally, one wonders how borderlanders have continued to maintain or have created new transnational links outside of Italy, in spite, or perhaps because, of the borders. Of course, in more contemporary studies, such research is well underway. As Peterlini remarks in his chapter, in a transnational world, whose economy, cultural production, sports and entertainment industry is globalized, neither migration nor the protection of minorities can be portrayed as a disturbance. It is rather the national State that unmasks itself as the expression of some phantasms of unity and purity that does not meet real life. ${ }^{41}$ The emergence of more extensive international and transnational entities, such as the European Union, has created much more porous borders; at the same time, the recent migrant crises have illustrated that alongside the dismantling of some borders has come the establishment - or at least the attempted establishment - of new, often fiercely guarded walls.

Acknowledgements. Thanks so very much to Christian Bailey, Emile Chabal, Victoria Harris and, of course, Malcolm McLean for their thoughtful review of and suggestions for this article.

41 Peterlini, 'Between Stigma and Self-Assertion', in Ibid., 354.

Cite this article: McLean E (2021). What Does It Mean to Be a(n Italian) Borderland? Recent Literature on Italy's 'New Provinces' of South Tyrol and the Julian March. Contemporary European History 30, 449-459. https://doi.org/10.1017/ S0960777320000545 